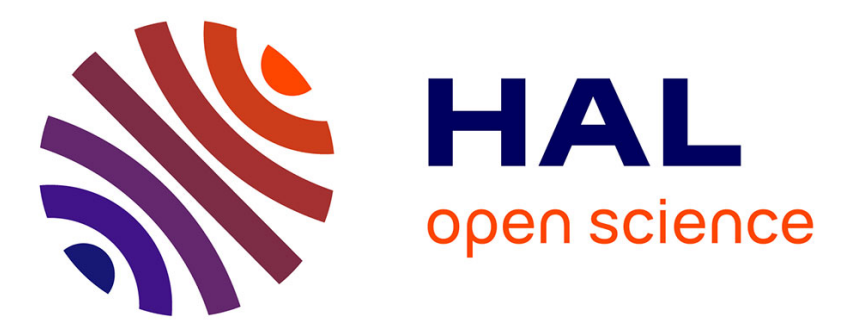

\title{
A proposal for the revewal of sectoral approaches building on the Cement Sustainability Initiative
}

Gregory Cook, Jean-Pierre Ponssard

\section{To cite this version:}

Gregory Cook, Jean-Pierre Ponssard. A proposal for the revewal of sectoral approaches building on the Cement Sustainability Initiative. 2012. hal-00681313

\section{HAL Id: hal-00681313 \\ https://hal.science/hal-00681313}

Preprint submitted on 21 Mar 2012

HAL is a multi-disciplinary open access archive for the deposit and dissemination of scientific research documents, whether they are published or not. The documents may come from teaching and research institutions in France or abroad, or from public or private research centers.
L'archive ouverte pluridisciplinaire HAL, est destinée au dépôt et à la diffusion de documents scientifiques de niveau recherche, publiés ou non, émanant des établissements d'enseignement et de recherche français ou étrangers, des laboratoires publics ou privés. 


\title{
ECOLE POLYTECHNIQUE
}

A PROPOSAL FOR THE RENEWAL OF SECTORAL APPROACHES BUILDING ON THE CEMENT SUSTAINABILITY INITIATIVE

\author{
Gregory COOK \\ Jean-Pierre PONSSARD
}

Cahier $n^{\circ}$ 2011-31

\section{DEPARTEMENT D'ECONOMIE}

Route de Saclay

91128 PALAISEAU CEDEX

(33) 169333033

http://www.economie.polytechnique.edu/

mailto:chantal.poujouly@polytechnique.edu 


\title{
A proposal for the renewal of Sectoral Approaches
}

\section{building on the Cement Sustainability Initiative}

\author{
Gregory Cook (Carbon Counts Ltd) \\ \& \\ Jean Pierre Ponssard (CNRS and Ecole Polytechnique)
}

April 2011

\begin{abstract}
The prospects for an international agreement within the United Nations Framework on Climate Change (UNFCCC) resulting in a common carbon price - such as a global cap and trade scheme - can for now only be seen as a long term goal. In the meantime, we have to work in a world of unilateral climate policies, eventually loosely coordinated among a limited number of countries. Two key considerations need be addressed in the design of these policies: equity for emerging countries, and competitiveness for carbon intensive internationally traded sectors. This context has generated a renewed interest in sectoral approaches. This paper provides a sound methodological framework to discuss equity and efficiency issues in sectoral approaches, makes a proposal that addresses these national requirements, and discusses some related implementation issues. The proposed approach combines basic components put forward by industry such as absolute caps for industrialized countries and intensity targets for emerging countries, BTA for those countries that do not adopt the sectoral approach, as well as reduced eligibility of these countries to benefit from the financial transfers collected through $\mathrm{CO}_{2}$ revenues in industrialized countries. The proposal is applied to the case of the cement industry.
\end{abstract}




\section{A proposal for the renewal of Sectoral Approaches}

\section{building on the Cement Sustainability Initiative}

1. Copenhagen: a stalemate for a worldwide carbon price agreement

Copenhagen marked a stalemate for the introduction of a uniform worldwide $\mathrm{CO}_{2}$ price along the lines of the EU ETS. Whatever its economic merits, the comprehensive approach suggested in 1992 by Richard Stewart and Jonathan Wiener (Stewart and Wiener, 1992) can now only be seen as a long term goal. In the meantime, we have to work in a world of unilateral climate policies, eventually loosely coordinated among a limited number of countries (Droege et al., 2009).

Among the reasons making such a top-down approach to climate policy unrealistic there are two which deserve more attention: the first one concerns equity issues and relates to the fact that many emerging countries are at most willing to commit only to intensity targets; the second one concerns competitiveness issues and relates to the capacity of carbon intensive industries to significantly constrain the commitments of industrialized countries to absolute targets. ${ }^{1}$

The recent Cancun Summit managed to achieve a constructive agreement in spite of this set of constraints. It encouraged international mitigation cooperation in deforestation (through establishing an incentive framework to encourage REDD ${ }^{2}$ activities), a carbon intensive sector with no international competition, promoted national measures by individual countries eventually supported by financial transfers to the poorest countries. This limited outcome has been interpreted as a possible renewal for sectoral approaches, in spite of the pejorative judgments often heard concerning their use (e.g. Fujiwara N, 2010).

A sectoral approach represents a combined industry and government initiative. Such an approach stipulates that for those countries signed up to the agreement, there are joint binding rules to mitigate $\mathrm{CO}_{2}$ emissions in some industries. As a matter of principle, these rules must be quite flexible. For example, they may include a cap and trade system, a set of

\footnotetext{
${ }^{1}$ For an extensive discussion of the underlying forces that have shaped international climate negotiations since Kyoto 1992, and the role of these two forces in particular in pervading the initial goal, see Godard, 2011a.

${ }^{2}$ Reducing Emissions from Deforestation and Forest Degradation (REDD).
} 
intensity targets or a set of technical norms. They may apply to one sector or to several sectors at once. They may also differ from one country to another. Baron (2009) and The Center for Clean Air Policy (2010) provide an exhaustive analysis of the various forms that a sectoral approach may take.

Historically, sectoral approaches could be seen as defensive tools promoted by industry to defer climate regulation (Morgenstern and Pizer, 2007). They could also be seen as a second best approach leading to inconsistencies and economic inefficiencies (Tirole, 2009).

This paper takes a different attitude towards sectoral approaches and explores some conditions under which they could play a positive role in the next round of international negotiations, along the lines suggested by Wooders (Wooders, 2010). ${ }^{3}$ We start from one sector, cement (indeed often listed with steel as a prime candidate for sectoral approaches, see Dröge et al, 2009). We then extend this industry approach into a larger framework in which some countries adopt cap and trade policies while others don't, with transfer policies directly linked to the adopted sectoral approach. Finally, we highlight how requirements for national sovereignty can be maintained, including priorities such as preserving national development or mitigating competitiveness issues.

\section{The Cement Sustainability Initiative as a starting point}

Cement is an important example to use in a discussion of sectoral approaches. It is a highly carbon intensive industry, ranking second only to lime in terms of value at stake from carbon costs (Hourcade et al., 2008). Also, it is a relatively homogenous traded commodity that has been identified at potential risk from competitiveness and leakage impacts (see for example Demailly and Quirion, 2008, and Ponssard and Walker, 2008). ${ }^{4}$

At the world level the industry is fairly concentrated. Consolidation is an ongoing trend and given demand patterns and recent events leading to collapsing sales in many OECD countries, cement firms are seeking geographic diversification and gaining footholds in important emerging markets. The world cement industry may thus be seen as a network of regional oligopolies (see Ghemawat and Thomas, 2008). Major cement firms such as Cemex, Holcim and Lafarge typically operate a large number of plants. ${ }^{5}$ The existence of such networks allows these firms to optimize their sourcing of production at any point in time depending on local supply and demand conditions. At this stage of market consolidation a

\footnotetext{
${ }^{3}$ This paper focuses on implementation issues. For a theoretic analysis of the proposed scheme, the reader is referred to Meunier and Ponssard, 2010.

${ }^{4}$ Its degree of openness to international competition is selective: cement is costly to transport on land but not on sea, which makes most coastal regions easily accessible to imports.

${ }^{5}$ According to their 2009 websites, Cemex operates in 79 plants (in 50 countries), Holcim 151 plants (in 70 countries, and Lafarge 166 plants (in 79 countries).
} 
sectoral agreement reached between just a handful of countries/parties (including the EU, US, China and India) could cover around $80 \%$ of world production. ${ }^{6}$

to the industry is highly sensitive to carbon costs: given a typical EU price range of $€ 80-100 / t$ and an average $\mathrm{CO}_{2}$ intensity of $0.7 \mathrm{tCO}_{2} / \mathrm{t}$ cement, then a a $\mathrm{CO}_{2}$ price of $30 € / \mathrm{t}$ would result in a cost increase of $0.7 * 30=21 € / t$ i.e. approximately $25 \%$ of the current price range. Ponssard and Walker's analysis suggest that sector pass through rates are fairly limited (particularly for coastal producers), and this is confirmed by some empirical data (e.g. Walker, 2007). The introduction of a unilateral climate policy such as the EU ETS may have a considerable impact on international trade flows and on future investments - although this has not been observed at this stage (see Ellerman and al. 2010 for an assessment of EU ETS Phase I, and Meunier and Ponssard, 2009, for an argument regarding the potential impact on future investment).

In recent years, the cement industry has been active in promoting a form of sectoral approach to reducing $\mathrm{CO}_{2}$ emissions. The corresponding work has been undertaken by the Cement Sustainability Initiative (CSI), an industry initiative involving the major multinational cement producers including some Chinese producers. It covers around $30 \%$ of world production (and 73\% of Annex 1 production. The CSI started operations in 2000 through a research phase and in 2002 developed an agenda for action with measurable targets and individual company commitments. A number of reports were issued in 2009 including "Getting the Numbers Right" (GNR) (within which producers report on their energy and $\mathrm{CO}_{2}$ performance), a proposal for a new sectoral Clean Development Mechanism, ${ }^{7}$ a Technology Road Map for cement (developed in collaboration with the IEA), and the conclusions of the Sectoral Approach modeling project. ${ }^{8}$

The Sectoral Approach proposed by the CSI is particularly interesting: it is elaborate but remains incomplete. Scenarios explore possible responses of the global cement industry over the period 2005 to 2030 assuming future demand in the various world regions, available technologies, including present and future abatement opportunities (e.g. energy efficiency, fuel switching, increased blending, carbon capture), production and transport costs.

Four key scenarios are compared:

1. Sectoral Approach, which assumes that Annex 1 countries commit to deep global targets for industrial $\mathrm{CO}_{2}$ emissions, while non-Annex 1 countries commit to intensity targets (adjusted on a country by country basis);

2. "No commitments", in which no $\mathrm{CO}_{2}$ regulations are implemented;

\footnotetext{
${ }^{6}$ According to latest US Geological Society data, hydraulic cement production in 2008 : China (1,388 Mt); EU (230 Mt) ; India (177 Mt) ; United States (88 mt) ; Japan (63 Mt) ; South Korea (54 Mt) ; Russia (54 Mt) ; Brazil (52 Mt) ; Turkey (52 Mt) ; Mexico (48 Mt).

${ }^{7}$ The CSI proposal was for a new CDM methodology based on simple benchmarks for cement and clinker plant.

${ }^{8}$ See http://www.wbcsdcement.org/ for details of climate change related work and initiatives.
} 
3. Global Caps, based on a uniform global $\mathrm{CO}_{2}$ price; and

4. an EU Caps-only scenario in which $\mathrm{CO}_{2}$ regulation is only implemented in the EU.

A key conclusion of the model is that for total cement demand of $5200 \mathrm{Mt}$ of cement in 2030, sector $\mathrm{CO}_{2}$ emissions would rise to $3500 \mathrm{Mt}$ under the "no commitments" reference scenario, $2000 \mathrm{Mt}$ with a Global Cap and $2600 \mathrm{Mt}$ with the Sectoral Approach. The latter scenario is considered to be a feasible target. However, the proposal appears incomplete in two ways: it does not address the issue of competitiveness and falls short of describing important implementation issues including e.g. how to attract the various stakeholders into the deal, and in particular why governments might buy into such a Sectoral Approach. These two issues are interdependent.

The role of competitiveness can be examined in the context of the EU-only scenario. The implementation of this scenario would generate a carbon leakage to reduction ratio of $56 \%$ that is, for every tonne of $\mathrm{CO}_{2}$ reduced in the $\mathrm{EU}$, there would be a corresponding $0.56 \mathrm{tCO}_{2}$ increase in the rest of the world (associated with increased foreign cement production to meet EU demand). This figure is in line with other studies which seek to model cement sector leakage potential (Meunier et al., 2011) and illustrates the limitations of unilateral policies introduced to address what is essentially a global problem.

The CSI suggests two possible approaches to deal with this competitiveness and leakage issue. It proposes the introduction of border tax adjustments (BTA), or else the allocation of free allocation to European cement firms. The European Commission has not chosen the first option, , although the use of border adjustments have not been ruled out for future use The second option has been adopted for the third phase of the EU ETS, wherein a large share of European industrial emissions will be eligible for free allocations until 2020, with a composite system of benchmarking. Notwithstanding the various concerns raised concerning their compatibility with international trade agreements, the current policy context makes it worthwhile reassessing the first option. At present, the feasibility of an inclusive international agreement based on a uniform $\mathrm{CO}_{2}$ price is some way off in the future, renewing interest in the use of BTA. The free allocation mechanism could however also be revisited as a potential source of financial transfer to assist mitigation in developing countries along the lines decided in Cancun (e.g. the Green Climate Fund).The rest of the paper explores the architecture of a Sectoral Approach. It builds upon the CSI proposal and introduces these new elements.

\section{From the CSI proposal to an enhanced sectoral approach}

We propose an Enhanced Sectoral Approach (or ESA), as illustrated below in table 1. The ESA could build upon the CSI approach (step 1), address competitiveness and leakage concerns through the use of BTA (step 2), and increase further the feasibility of financial transfers to alleviate equity issues (step 3). 
Annex 1 (A1) countries and some non Annex 1 countries (SNA1) are assumed to adopt the ESA, while other non Annex 1 (ONA1) do not. The approach is now described in further details.

Table 1: Summary of an Enhanced Sectoral Approach

\begin{tabular}{|c|c|c|c|c|}
\hline & \multicolumn{2}{|c|}{ Countries included in the ESA } & \multirow{2}{*}{$\begin{array}{l}\text { ONA1 countries } \\
\text { (rest of world) }\end{array}$} & \multirow{2}{*}{ Key issues } \\
\hline & A1 countries & SNAI countries & & \\
\hline BAU & \multicolumn{2}{|r|}{ BAU } & & $\begin{array}{c}\text { Climate change mitigation not } \\
\text { addressed }\end{array}$ \\
\hline & \multicolumn{2}{|c|}{ Technology roadmap } & \multirow{3}{*}{ BAU } & \multirow{2}{*}{$\begin{array}{l}\text { Equity partially addressed in } \\
\text { SNAI through use of intensity } \\
\text { targets; } \\
\text { Competitiveness and leakage } \\
\text { issues arise from differential } \\
\mathrm{CO}_{2} \text { prices between A1, SNA1 } \\
\text { and ONA1 }\end{array}$} \\
\hline Step 1 (CSI) & $\begin{array}{l}\text { Cap and trade with } \\
\text { absolute targets; } \\
\text { Free allocation to } \\
\text { cement firms }\end{array}$ & $\begin{array}{l}\text { Sector intensity } \\
\text { target }\end{array}$ & & \\
\hline Step 2 & $\begin{array}{c}\text { Elimination of free } \\
\text { allocation; } \\
\text { BTA on ONA1 imports }\end{array}$ & $\begin{array}{l}\text { Export taxes on } \\
\text { cement and clinker } \\
\text { from SNA1 to A1 }\end{array}$ & & $\begin{array}{l}\text { Competitiveness and leakage } \\
\text { issues are addressed }\end{array}$ \\
\hline Step 3 (ESA) & $\begin{array}{c}\text { Financial transfers } \\
\text { from A1 to SNA1 (from } \\
\text { allowance auction } \\
\text { revenues) }\end{array}$ & $\begin{array}{l}\text { Higher eligibility for } \\
\text { financial transfers }\end{array}$ & $\begin{array}{l}\text { Lower eligibility for } \\
\text { financial transfers } \\
\text { (which incentivises } \\
\text { move from BTA to ECA } \\
\text { participation) }\end{array}$ & $\begin{array}{l}\text { Feasibility of financial transfers } \\
\text { is facilitated through increased } \\
\mathrm{CO}_{2} \text { revenues in } \mathrm{A} 1 \text { countries }\end{array}$ \\
\hline
\end{tabular}

We start with step 1. The CSI technology road map may be used in the ESA countries to set standards either for $\mathrm{CO}_{2}$ intensity targets in SNA1 or for the allocation of free allowances in industrialized countries (A1) that have adopted cap and trade systems such as the EU-ETS. To be effective a free allocation approach needs to be output based rather than based on grandfathering (Quirion, P. 2009). However, an output based approach has an important drawback: it eliminates the carbon price signal to consumers and thereby the incentive to switch consumption towards alternative and less carbon intensive products. Technically, the EU ETS during 2013-2020 will have similarities with an output based approach. ${ }^{9}$ However, the actual implementation of such a system appears complicated: it is awkward to monitor (allocations are based on thresholds of past used capacities), it will not favor industry restructuring within the EU (a number of small inefficient plants need be closed), and it may not even reduce the incentive for firms to relocate production outside of the EU (some

\footnotetext{
${ }^{9}$ Draft_Commission_decision_ETS_allocation_rules_101125-2.pdf
} 
gaming within the system may allow for maintaining free allocations while importing). Furthermore, the very fact of introducing free allocations for some sectors has led to an inflation of so-called exposed sectors: 147 out of a total of 256 sectors have been declared exposed, amounting to $75 \%$ of industrial emissions, excluding the production of energy. ${ }^{10}$

Step 2 addresses competitiveness and leakage issues in two ways. ${ }^{11}$ It introduces BTA on imports from ONA1 countries. For SNA1 countries we propose that they directly monitor an export tax based on the $\mathrm{CO}_{2}$ emission content of their exports to $\mathrm{A} 1$ countries, using the prevailing $\mathrm{CO}_{2}$ price in the country of export destination. Exporters then have an option to provide alternative data if this is better than the default factors chosen. ${ }^{12}$ As a consequence of these two measures, free allocation to cement producers in A1 could be eliminated since we now have a level playing field for the cement sector worldwide, as far as carbon pricing is concerned. The price signal for incentivising reduced cement consumption is back in A1 countries. Step 2 is a clear conceptual improvement over step 1.

Step 3 sets the stage for financial transfers from industrialized countries to emerging countries, as agreed at Copenhagen and Cancun. Our idea builds on this proposal, both in terms of the origins of the funds and in terms of their destination. In terms of funding we propose that part of the transfers come from revenues collected through the auctioning of $\mathrm{CO}_{2}$ emission rights in $\mathrm{A} 1$ countries. The fact that free allocation in industrialized countries is eliminated increases the amount of revenues from $\mathrm{CO}_{2}$ auctioning. Regarding how such transfers could be used, we propose that a (SNAI) country that joins the ESA would see its share of these transfers being increased. In this way there would be a clear incentive for countries to join the agreement. Indirectly, such countries would also benefit from the change from a BTA regime to an export tax regime, since under the proposed approach, the export taxes remain in the country of origin.

Our step 3 goes further and proposes that these financial transfers be administered as sectoral approaches and not as offsets - as per the current CDM approach. As an illustration, consider the electricity sector in China with funds originating from allowance auctioning in the EU. Some of the financial transfers would be earmarked for achieving sector emission intensity goals through covering the incremental cost of abatement; all eligible projects in the electricity sector would be considered at a sector level rather than on a project basis (as has been the case for example with wind farms developed in China under the CDM, see Gang He and Morse, 2010). Earmarking funds for a specific country and sector makes this possible and eliminates much of the criticisms made against the CDM (Schneider, 2007, Wara, 2007, Victor and Wara, 2008).

\footnotetext{
${ }^{10}$ See for instance http://ec.europa.eu/environment/climat/emission/carbon en.htm

${ }^{11}$ In general equilibrium models, leakage in a world of unequal carbon prices comes from a (small) direct competitiveness impact on internationally traded sectors and a (large) indirect impact coming from the price changes in energy goods (Kuik, 2001, O. Kuik, (2001), The effect of trade liberalization on carbon leakage under the Kyoto protocol: experiments with GTAP-E, Paper prepared for the 4th Annual Conference on Global Economic Analysis, June 27-29, Purdue University). Sectoral BTA has no impact on the second factor, yet it may be necessary to induce industry to go from step 1 to step 2 .

${ }^{12}$ For a recent review of the political issues associated with BTA, such as compatibility with the WTO see Godard 2011 b.
} 


\section{Implementation issues}

In this section we discuss how this proposal bypasses a number of traditional arguments against SA. Specifically, we first review how targets and baselines can be defined for intensity based for SNA1 countries. We then clarify the relationships between the three types of countries (A1, SNA1 and ONA1) with respect to export taxes and border adjustments, and with respect to financial transfers.

For emission reductions to be considered meaningful, national targets $\left(\mathrm{tCO}_{2}\right.$ per tonne cement produced) must be framed so as to constitutes real effort beyond a BAU baseline. There are different options here: if the form of the target were to be based on an agreed \% reduction in intensity over a certain period (perhaps annually) then this would require an assessment of potential BAU projection of sector carbon intensity. GNR data indicates that sector performance has improved in all world regions over recent years, and this trend is expected to continue as e.g. blending rates and use of alternative fuels increase and older kilns are closed. A sector-focused approach, e.g. involving country-specific targets for new and existing facilities might therefore be more appropriate. A similar approach, based on clinker and cement benchmarks for new and existing installations has indeed been proposed by the CSI as the basis for a new simplified CDM methodology to replace the more complex mix of existing approved methodologies pertaining to cement plants.

The need to ensure target stringency remains a key requirement however. Both targets and baselines must also serve to fairly reflect national factors, including fuel use, materials availability and existing technology. Targets must be based on what is technically feasible and at what economic cost across the participating countries: while new plant is now standard and BAT on a global basis (i.e. large plants using dry process where available deploying kiln pre heater and pre-calciner technology), existing plant can vary considerably by region, as can the abatement options available. Local circumstances and capabilities are thus important factors. In this context, intensity targets would likely need to be developed through an output based allocation approach aiming to equalise marginal abatement costs between countries.

An important policy issue concerns the actual process by which targets and baselines can be developed and agreed between participating countries and several studies have considered the development and negotiation of sector targets within a UNFCCC framework (e.g. CCAP, IEA). A key benefit of a sectoral approach however is that, by focusing on one sector only and a handful of key producing countries, such an approach could help speed up the effectiveness of abatement efforts and opportunities without relying on the strained process of UNFCCC negotiations. The role of host (SNAI) governments would however be hugely important, both in their involvement in reaching agreements and in establishing the appropriate national supporting policies and measures to assist the cement sector in meeting the targets (e.g. amending building and product codes, incentivizing energy efficiency through best practice schemes and energy subsidy removal, improving national waste management and biomass availability). In this way, sectoral agreements reached 
within the cement and other industrial sectors could be implemented by SNAI as part of Nationally Appropriate Mitigation Actions (NAMAs).

Industry experts drawn from A1 and SNAI or third party countries could form a panel to assess proposed baselines and targets forwarded by each of the participating countries and assess BAT and national circumstances. As with all effective mitigation policy, such a system would require robust and common approaches to monitoring reporting and verification (MRV) and the CSI/GNR provides a useful basis. Although intensity targets require additional data sources (i.e. output) these would likely not be problematic for the sector: unlike many other sectors, cement and clinker are reasonably simple homogenous products which do not give rise to complex definitional and product scope considerations. However, in theory at least, there would be an Incentive for SNAI countries to overstate production levels (in relation to emissions levels) and so, as with the emissions MRV requirements, a third party verification agreement relating to plant production might be envisaged.

There are also some important issues to consider in the design and implementation of a BTA applied to the ONAI countries. The administrative requirements, costs and technical practicality of accurately determining the level of emissions linked to BTA may be the greatest barrier to their implementation (Reinaud, 2009). The development of robust plantlevel MRV requirements is costly and resource-intensive, requiring a significant amount of political and administrative effort in low-cost producing countries located in e.g. developing Asia and Africa. Because a commonly agreed and robust MRV approach allowing for plantby-plant data collection does not exist globally, some form of simplification would inevitably be required, at least in the near term.

Although not as pronounced as in other sectors, the degree of carbon intensity variability within the cement industry means that calculating the carbon content of imported clinker and cement on the basis of simple BAT benchmarking may still give rise to domestic producers facing higher carbon costs than those levied on imports. Similarly, a more stringent use of simple benchmarking (i.e. a high $\mathrm{tCO}_{2}$ per $\mathrm{t}$ clinker/cement) would unfairly penalise against many foreign producers.. Table 2 below compares these two extremes - a plant-by-plant system and the use of import benchmarking - with an alternative approach. The latter, based on a set of suitably stringent default factors but with the option available to producers to demonstrate their plant-level emissions intensity would appear to represent a sensible and practical compromise. Importantly, such an approach may incentivise greater use of plant-by-plant MRV, thereby acting as useful bridge to a full plant-by-plant assessment of carbon content (and a basis for ONAI participation in the ESA). 
Table 2: Summary of BTA design options

\begin{tabular}{|c|c|c|c|}
\hline Option & Advantages & Disadvantages & Overall assessment \\
\hline $\begin{array}{l}\text { Plant-by-plant } \\
\text { assessment }\end{array}$ & $\begin{array}{l}\text { Carbon intensity of imported } \\
\text { products determined with } \\
\text { greatest level of accuracy, } \\
\text { thereby maximising BTA } \\
\text { effectiveness and limiting legal } \\
\text { disputes under WTO }\end{array}$ & $\begin{array}{l}\text { Imposes significant } \\
\text { administative burden, cost and } \\
\text { time to develop robust MRV } \\
\text { approaches. Requirement for } \\
\text { foreign action would require } \\
\text { much policy effort }\end{array}$ & $\begin{array}{l}\text { Practical and politcal } \\
\text { challenges likely to limit } \\
\text { feasibility in the short-term. CSI- } \\
\text { GNR programme may provide } \\
\text { workable basis for such an } \\
\text { approach over longer-term }\end{array}$ \\
\hline Benchmarking & $\begin{array}{l}\text { Benchmarking on basis of BAT } \\
\text { of performace is simple and } \\
\text { avoids extensive MRV } \\
\text { requirements with associated } \\
\text { political issues }\end{array}$ & $\begin{array}{l}\text { Determning appropriate level } \\
\text { poses significant challanges. A } \\
\text { too stringent level would } \\
\text { penalise some exporters, } \\
\text { raising WTO legal issues; a } \\
\text { level set too low could only } \\
\text { partially equalise carbon costs, } \\
\text { limiting effectivenss of BAM }\end{array}$ & $\begin{array}{l}\text { Choice of level based on BAT or } \\
\text { best performance would be } \\
\text { relatively workable and } \\
\text { potentially avoid legal issues. } \\
\text { However, competitvness and } \\
\text { leakage concerns would only be } \\
\text { partially addressed }\end{array}$ \\
\hline $\begin{array}{l}\text { Default factors with } \\
\text { option for plant-level } \\
\text { evidence }\end{array}$ & $\begin{array}{l}\text { Combines simplicity of } \\
\text { bechmarking approach with } \\
\text { stringency (and therefore } \\
\text { effectiveness) of plant-by-plant } \\
\text { asessment. May incentivise } \\
\text { greater use of MRV within } \\
\text { sector globally }\end{array}$ & $\begin{array}{l}\text { Many design issues relavant to } \\
\text { other options remain, including } \\
\text { e.g. choice of appropriate } \\
\text { default factor and basis for } \\
\text { MRV protocol acceptable to } \\
\text { domestic regulator }\end{array}$ & $\begin{array}{l}\text { Presents potentially workable } \\
\text { compromise in the context of } \\
\text { the cement sector and potential } \\
\text { bridge to plant-by-plant } \\
\text { assessment }\end{array}$ \\
\hline
\end{tabular}

Applying a range of default factors on the basis of some key criteria would appear a sensible approach to reducing the inaccuracy of a simple BAT-type approach. Under most US proposals for border adjustments, for example, the carbon content of imported goods would be assessed using a national average for the country of origin. What would be the most appropriate basis for such an approach for the cement sector? Factors based on $\mathrm{CO}_{2}$ per tonne of clinker are likely to represent the most workable approach: developing cement factors would be more complex due to product definition and process complications.. However, applying pure clinker benchmarking to all products would have the disadvantage of not rewarding greater use of clinker substitution (a key abatement lever for the sector). A potential approach could therefore be the use of pure clinker benchmarks combined with average national clinker content factors - based on equivalent cement, meaning cement produced from own produced clinker. Concerning the scope of emissions coverage within such an approach, the complexities involved in determining regional grid emissions intensity combined with the relatively low use of electricity in cement production suggest little benefit in seeking to include indirect $\mathrm{CO}_{2}$ emissions. Certain elements may require modification through suitable formulations: for example, the potential for carbon price spikes arising in the A1 market, which by dramatically increasing BTA, could present political difficulties.

The introduction of export taxes by SNA1 countries is unlikely to present any novel issues. Many cement producing regions (including key producers such as Egypt and China) have 
developed existing procedures for applying various taxes and/or rebates on clinker and cement exports, and accounting for plant-level emissions (and chain of custody from plant to port) does not pose a particular difficulty. The development of a suitably robust MRV system with third party verification again presents the key requirement of such a scheme. Another important feature is that such an approach would effectively require no enforcement or penalty system (other than a robust MRV system): financial transfers from A1 can be linked to SNAI country performance and those parties breaking the agreement (e.g. through misreporting data) could face the imposition of BTA. There are therefore 'sticks' as well as 'carrots' within the proposed ESA.

The above discussion notes a number of important implementation issues, all of which represent real, practical challenges. There will also be others, including how to fairly address 'comparability of efforts' from non-participating countries when calculating the (differential) carbon cost element of the BTA. Resolving these will clearly require further detailed study and some considerable effort from national governments. However, it appears that at least in the case of the cement sector, such considerations are not insurmountable. The specific characteristics of the industry and the successful development of the industry-led CSI/GNR data system - representing a potential framework for the required MRV arrangements suggest the suitability of the sector as an early candidate for developing a sectoral approach to achieving significant and verifiable GHG emission reductions.

\section{References}

Baron, R., B. Buchner, and J. Ellis, 2009. Sectoral Approaches and the Carbon Market. IEA/OECD paper.

Center for Clean Air Policy, 2010. Global Sectoral Study: Final Report to the European Commission. Washington DC.

Demailly, D. et P. Quirion, 2008. Leakage from Climate Policies and Border Tax Adjustment: Lessons from a Geographic Model of the Cement Industry?, Chapitre 16 dans Roger Guesnerie et Henry Tulkens, éditeurs, The Design of Climate Policy, papers from a Summer Institute held in Venice, CESifo Seminar Series, Boston: The MIT Press.

Droege, S., et al., 2009. Tackling Leakage in a World of Unequal Carbon Prices, Climate Strategies, July.

Ellerman D. A., F. J. Convery et C. de Perthuis, 2010. Pricing carbon The European Union Trading Scheme, Cambridge University Press.

Fischer, C., 2001. Rebating Environmental Policy Revenues: Output-Based Allocations and Tradable Performance Standards." Resources For the Future, Discussion Paper, 0122. 
Fujiwara N. 2010. The merit of sectoral approaches in transitioning towards a global carbon market. CEPS.

Gang He and R. K. Morse, 2010. Making carbon offsets work in the developing world; lessons from the Chinese wind controversy. Working Paper 90, PESD, Stanford University.

Ghemawat, P. and C. Thomas. 2008. Strategic Interaction across Countries and Multinational Agglomeration: An Application to the Cement Industry. Management Science. 54, 19801996.

Godard, O., 2011a. Une mise en perspective historique des négociations internationales sur un régime de protection du climat, in Economie du Climat Pistes pour l'après Kyoto, 0. Godard and JP Ponssard (ed.) Editions de l'Ecole Polytechnique, Palaiseau., $310 \mathrm{p}$.

Godard, O., 2011b. Intégrité environnementale des politiques climatiques et ajustement aux frontières: les enjeux pour l'Union européenne, in Economie du Climat Pistes pour l'après Kyoto, O. Godard and JP Ponssard (ed.) Editions de l'Ecole Polytechnique, Palaiseau., 310 p.

Hamdi-Cherif, M., C. Guivarch and P. Quirion, 2009. Sectoral Targets for Developing Countries: Combining "Common but Differentiated Responsibilities" with Meaningful Participation. to appear in Climate Policy.

Hourcade, J.-C., D. Demailly, K. Neuhoff et M. Sato, 2007. Differentiation and dynamics of EU ETS competitiveness impacts, Climate Strategies report.

Meunier, G. and J.-P. Ponssard, 2009. Capacity Decisions with Demand Fluctuations and Carbon Leakage, Working Paper, Ecole Polytechnique, August.

Meunier $G$ and J-P Ponssard, 2010. A sectoral approach balancing global efficiency and equity. Ecole Polytechnique. Working Paper, Ecole Polytechnique, April.

Meunier, G, S. Monjon and J-P Ponssard, 2011. Compétitivité et fuites de carbone dans le cadre de politiques climatiques unilatérales in Economie du Climat Pistes pour l'après Kyoto, O. Godard and JP Ponssard (ed.) Editions de l'Ecole Polytechnique, Palaiseau., 310 p.

Morgenstern, R. D., and Pizer. W., 2007. Reality Check : the nature and performance of voluntary environmental programs in the United States, Europe and Japan. United States: Resources for the Future, 189 p.

Ponssard, J-P. and N. Walker, 2008. EU Emissions Trading and the cement sector: A spatial competition analysis, Climate Policy, 8, 467-493.

Quirion, P., 2007. Comment faut-il distribuer les quotas échangeables de gaz à effet de serre." Revue française d'Economie, 22, 129-164. 
Quirion, P. 2009, Historic versus output-based allocation of GHG tradable allowances: a survey, Climate Policy, 9: 575-592

Reinaud, J., 2008. Climate Policy and Carbon Leakage: Impacts of the European Emissions Trading Scheme on Aluminium, IEA Information Paper, OECD/IEA, Paris.

Reinaud, J., 2009. Trade, Competitiveness and Carbon Leakage: Challenges and Opportunities, Chatham House, London.

Schneider, L., 2007. Is the CDM fulfilling its environmental and sustainable development objectives? An evaluation of the CDM and options for improvement. Oko-Institut, report for the WWF.

Stewart, R.B. and J.B. Wiener, 1992. The Comprehensive Approach to Global Climate Policy: Issues of Design and Practicality, Arizona Journal of International and Comparative Law, 9(1), pp. 83-114.

Victor, D. and M. Wara, 2008. A Realistic Policy on International Carbon Offsets. Technical report, Working Paper 74. Stanford, USA.

Walker, N., 2007. Emissions Trading and Cement: What does the empirical data suggest? Presentation.

Wara, M., 2007. Measuring the clean development mechanism's performance and potential. UCLA Law Review, 55, 17-59.

World Business Council for Sustainable Development, 2009. A Sectoral Approach. Cement Sustainability Initiative. Geneva.

WRI, 2006. Target: Intensity - An analysis of greenhouse gas intensity targets. World Resources Institute, Washington D.C.

Wooders, P. (2010) Exploding the Myths of Sectoral Approaches. Climate Strategies. 